\title{
The heat analysis of Chinese enterprises in Laos transportation infrastructure investment under the "The Belt and Road Initiative"
}

\author{
Xinran Ge \\ International Business School \\ Yunnan University of Finance and Economics \\ Kunming, China \\ 359362979@qq.com
}

Ersi Liu

International Business School

\author{
Yunnan University of Finance and Economics \\ Kunming, China \\ Liuersi309@126.com
}

\author{
Ke Yan * \\ International Business School \\ Yunnan University of Finance and Economics \\ Kunming, China \\ 543487184@qq.com
}

\begin{abstract}
China and Laos have a very long tradition of trade, in recent years, with the "The Belt and Road initiative" is proposed, the Chinese enterprise investment in Laos has entered a new period of development. At the same time, the development of transportation infrastructure is very poor, which seriously restricts the overall economic development of Laos. In this paper, the heat analysis method is used to analyze the investment environment of transportation infrastructure in Laos, which provides a guiding role for the investment of Chinese enterprises in Laos.
\end{abstract}

Key words - "The Belt and Road Initiative" ; transport infrastructure; the heat analysis

\section{INTRODUCTION}

China and Laos has been adhering to good neighborly relations. In September 2009, the cooperation between China and Laos rapid warming, the two sides established a full range of strategic partnership and bilateral trade and economic, political, military, cultural and other aspects to strengthen cooperation, is worthy of the name of a good neighbor and partner relationship. In recent years, with the deepening economic cooperation between the two countries, the bilateral trade volume rising, a large number of Chinese enterprises have entered the Laos local, which greatly promoted the local economic development and provided a large number of employment opportunities for local residents. According to statistics of China's Customs, in 2014, bilateral trade between China and Laos is $\$ 1.84$ billion, with an increase of $32.4 \%$. Among them, China's exports reached $\$ 1.84$ billion up 7\%; imports reached \$ 1.78 billion, and it jumped $75.7 \%$ [1]. Moreover, Laos is an important nation to develop "The Belt and Road Initiative", and it is also an important node connecting China and Southeast Asia and South Asia countries. However, the Laos transportation infrastructure is backward, which seriously restricts its development. China and Laos are geographically close, have always had a good trade relationship, therefore, it is beneficial to invest the transportation infrastructure in Laos under the background of "The Belt and Road Initiative" for the peoples of the two countries, and it also can achieve mutual benefit and a win-win outcome

\section{The ACtUALity OF NATION AND TRANSPORTATION INFRASTRUCTURE CONSTRUCTION IN LAOS}

Laos is located in the northern part of Indo-China Peninsula and on the border with China, Cambodia, Vietnam, Myanmar, Thailand, its land area is 236800 square kilometers, with a population of 6.5 million, belonging to the tropical monsoon climate, and the annual average temperature is around 28 degrees Celsius [2]. Laos is very rich in natural resources, including copper, iron, zinc, bauxite and other mineral resources, hydro-power resources are also very abundant.

However, Laos transportation infrastructure is very backward, at present, the country still does not have the highway, the railway is also a serious lack of.

\section{A. Road}

In Laos, the highway is the main pillar of transportation, as of $2015,79 \%$ of the country's transport come from the road, the passenger volume has reached 37.617 million, the freight volume has reached 3.659 million tons [3]

But there still are many questions about the road in Laos, as shown in Table I, the total length of the road although increased from 39590 kilometers by 2010 to $51600 \mathrm{~km}$ by 2014 [4], the proportion of pavement only from 13.7\% increased to $16.0 \%$, most of the rest are gravel roads and dirt roads, these roads almost can not be opened to traffic in the rainy season, which seriously affect the local people travel and domestic and foreign transport.

\footnotetext{
* Corresponding author
} 
TABLE I. LAOS'S ROAD CONDITION IN 2010-2014

\begin{tabular}{|c|c|c|c|}
\hline Year & $\begin{array}{c}\text { Length of road } \\
(\mathbf{k m})\end{array}$ & $\begin{array}{c}\text { Pavement } \\
(\mathbf{k m})\end{array}$ & $\begin{array}{c}\text { Proportio } \\
\mathbf{n} \\
\mathbf{( \% )}\end{array}$ \\
\hline 2010 & 39590 & 5427 & 13.7 \\
\hline 2011 & 41030 & 5703 & 13.9 \\
\hline 2012 & 43600 & 6496 & 14.9 \\
\hline 2013 & 45830 & 6888 & 15.0 \\
\hline 2014 & 51600 & 6272 & 16.0 \\
\hline
\end{tabular}

\section{B. Railway}

Before 2008, Laos is the absence of the railway. In Laos, the first railway is constructed by the Thai government with the investment of 1.97 billion baht, from Laos capital of Vientiane to the friendship bridge leading to the border of Laos and Thailand, the railway is 3.5 kilometers long, was completed in May 2008, and the official opened to traffic on 2009 March 5, Laos will bid farewell to the era of no railway. But as of the end of 2014, the territory of Laos is still only this section of railway.

\section{Inland shipping}

As of 2014, the total length of the Lao inland waterway is $4600 \mathrm{~km}$, and the volume of passenger traffic is 1.811 million passengers, freight volume is 883 thousand tons [5].

The Mekong River is an important pillar of the inland shipping in Laos, and it is known as the mother of all things for Lao people, the total length is more than $1800 \mathrm{~km}$ inside Laos, and the whole year can be navigable. But regulation work of the Mekong river is also very difficult, it is hard to finish only by Laos, the lower Mekong river segment from the Ban Houayxay is still not smooth [6]

\section{Airport}

There are 13 airports in Laos, including 4 international airports, 9 domestic airports. Major international routes include : Vientiane - Kunming, Vientiane - Nanning, Vientiane - Guangzhou, Vientiane - Bangkok, Vientiane Incheon, Vientiane - Hanoi, Vientiane - Ho Chi Minh City, Pakse - Siem Reap, Vientiane - Kuala Lumpur, Vientiane Singapore, Luang Prabang - Bangkok, Luang Prabang Jinghong, Luang Prabang - Chengdu. And the volume of passenger traffic is 0.44 million passengers, freight volume is 20 thousand tons [7] .

\section{ANALYSIS ON INVESTMENT ENVIRONMENT OF TRANSPORTATION INFRASTRUCTURE IN LAOS}

Traffic infrastructure is backward, which seriously restrict the development of Laos's economic. Therefore, the Laos government pay more and more attention to the traffic infrastructure construction, increase investment, actively strive for the other countries to invest in Laos's transport infrastructure.

\section{A. Admission of foreign investment}

According to the provisions of the Laos to promote investment law, in terms of investment manners for foreign investors, Laos has mainly taken the following four ways: joint ventures with the domestic and foreign investors, foreign investors to wholly-owned, joint venture agreement and contracted enterprises. Which foreign investors in a joint venture with the domestic and foreign investors should share of the total at least accounted for more than $10 \%$ of the total investment, and in accordance with the laws of the Lao, the investment in the form of foreign currency capital will be according to the exchange rate of investment of the Lao People's Democratic Republic bank folding into kip; wholly foreign-owned enterprises may be a new company form, can also be representative offices form in Laos (branches or representative), branch or representative in Laos must have own in accordance with the law and won the Laos Foreign Investment Management Department permits; joint venture agreement refers to a joint venture between a domestic enterprise and a foreign enterprise, and has not incorporated a new legal person or part; registered capital of the contracted enterprises can not be less than $30 \%$ of the total investment, the registered capital of the enterprise must be a tangible asset [9], while during the operation of enterprises, the total assets of the enterprise shall not be less than the registered capital.

In addition, industries that allow foreign investment include: agriculture, forestry, planting and processing industry, industry, transportation and construction industry, service industry.

\section{B. Tax regulation}

Laos implement a unified tax regulation, there are 6 types of taxes, divided into direct and indirect taxes, among them, direct taxes, including the profit tax, income tax, lump sum taxes, environmental taxes and procedures and the service fee, indirect taxes including value-added tax and consumption tax.

In terms of income tax, according to the provisions of the Lao government, enterprise employee salary, the cost of labor, enterprise chattel and real estate income, enterprise intangible assets (such as intellectual property rights, patents, trademarks, etc.) need pay the corresponding proportion of income tax in accordance with the provisions. In Laos, the income tax threshold is 30 million kip, specifically, 30 million - 150 million tax rate is $5 \%, 150$ million - 400 million tax rate is $10 \%, 400$ million - 800 million tax rate is $15 \%, 800$ million 1500 million tax rate is $20 \%$, the rate of more than 15 million is $25 \%$ [10].

In the income tax, the threshold is 60 million, the part of more than 60 million levied at 35\% [11].

\section{Labor capital}

Laos passed "labor law"(Revised Draft) in 2006, facing Laos's generally low quality of the labor force, technology and knowledge talents serious lack of, as well as Laos working with relatively low status, Laos "labor law" for labor wages, welfare, working hours have more accurately defined.

In terms of labor wage, Lao labor's average monthly salary is about $\$ 180$, the Laos government for the sixth time improve the national minimum wage standards, increased to 90 million kip in Laos [12] . 
TABLE II. $\quad$ LAOS’S WAGES IN 2015

\begin{tabular}{|c|c|c|c|}
\hline \multirow[b]{2}{*}{ Wages } & \multicolumn{2}{|c|}{ Average wage } & $\$ 180$ \\
\hline & \multicolumn{2}{|c|}{ Minimum wage } & $\begin{array}{l}900 \text { thousand Kip } \\
\text { (about } \$ 112 \text { ) }\end{array}$ \\
\hline \multirow{4}{*}{$\begin{array}{l}\text { Overtime } \\
\text { pay }\end{array}$} & \multirow{2}{*}{$\begin{array}{l}\text { Normal working } \\
\text { day }\end{array}$} & Day & $\begin{array}{c}150 \% \text { of the daily } \\
\text { wage }\end{array}$ \\
\hline & & Night & $\begin{array}{l}200 \% \text { of the daily } \\
\text { wage }\end{array}$ \\
\hline & \multirow{2}{*}{$\begin{array}{l}\text { Statutory } \\
\text { holidays }\end{array}$} & Day & $\begin{array}{c}250 \% \text { of the daily } \\
\text { wage }\end{array}$ \\
\hline & & Night & $\begin{array}{l}300 \% \text { of the daily } \\
\text { wage }\end{array}$ \\
\hline $\begin{array}{c}\text { Duty } \\
\text { allowance }\end{array}$ & \multicolumn{2}{|c|}{$22: 00 —$ next day $5: 00$} & $\begin{array}{c}15 \% \text { of the daily } \\
\text { wage subsidy }\end{array}$ \\
\hline
\end{tabular}

Labor welfare [13], the Lao government requires all employers must participate in social insurance. The social security paid by the government or enterprises and individuals to bear, the specific payment of the situation as shown in follow table.

TABLE III. LAO SOCIAL SECURITY PAYMENTS IN 2015

\begin{tabular}{|c|c|c|}
\hline Payment party & Insured person & $\begin{array}{c}\text { Social security fee } \\
\text { (monthly) }\end{array}$ \\
\hline Government & $\begin{array}{c}\text { All civil servants, } \\
\text { government employees, } \\
\text { military personnel and } \\
\text { police }\end{array}$ & $\begin{array}{c}8.5 \% \text { of the total } \\
\text { monthly salary }\end{array}$ \\
\hline Enterprise & Employee of the \\
enterprise & $\begin{array}{c}6 \% \text { of the total } \\
\text { monthly salary }\end{array}$ \\
\hline Individual & $\begin{array}{c}\text { State civil servants, public } \\
\text { officials, military } \\
\text { personnel, police officers }\end{array}$ & $\begin{array}{c}8 \% \text { of the total } \\
\text { monthly salary }\end{array}$ \\
\cline { 2 - 4 } & $\begin{array}{c}\text { Employee of the } \\
\text { enterprise }\end{array}$ & $\begin{array}{c}5.5 \% \text { of the total } \\
\text { monthly salary }\end{array}$ \\
\hline
\end{tabular}

\section{HEAT ANALYSIS OF THE INVESTMENT ENVIRONMENT OF TRANSPORTATION INFRASTRUCTURE IN LAOS}

Based on our above mass analysis, the investment environment of Laos transportation infrastructure is analyzed under the heat analysis by the method of inviting experts.

\section{A. Evaluation criterion}

According to the situation of the political, economic, financial, legal, social and cultural and so on in Laos, the evaluation index system of heat analysis is constructed. The first level indicators include: political environment, legal environment, economic environment, financial environment, labor market environment and natural environment. Second level indicators include: political stability, the ruling nature of the party, the nature of the country, the degree of democracy, the relevant laws and regulations perfect degree, foreign access conditions, tax policy, intellectual property protection, environment related laws and regulations, the gross national product, market scale, economic growth amplitude, inflation rate, to attract foreign investment, exchange rate, the development of securities market, banking institutions, financing convenience degree, the amount of labor, labor wages, labor welfare, labor quality, geographic location and natural resources.

According to the construction of evaluation index system, through the invitation of relevant experts to grade two indicators. Scoring range from 1 to 3 , scoring can take fractional form. Among them, the 0-1 divided into cold, namely the risk for investment of traffic infrastructure construction in Laos is large, so it is not conducive to foreign investment; 1-2 points for temperature, namely the risk of investment Laotian traffic infrastructure construction is moderate, foreign investors can invest; in 2-3 divided into heat, that is conducive to invest traffic infrastructure in Laos for foreign investors.

\section{B. Evaluation situation}

To evaluate the second level index by the method of inviting experts, we can get scoring results, as shown in follow table.

TABle IV. Evaluation Results of Heat IndeX System

\begin{tabular}{|c|c|c|}
\hline $\begin{array}{c}\text { The first level } \\
\text { indicator }\end{array}$ & The second level indicators & Score \\
\hline \multirow{4}{*}{$\begin{array}{c}\text { political } \\
\text { environment }\end{array}$} & political stability & 2.8 \\
\hline & the nature of the ruling party & 2.5 \\
\hline & the nature of the country & 2.5 \\
\hline & the degree of democracy & 2.0 \\
\hline \multirow{4}{*}{ legal environment } & $\begin{array}{l}\text { The complete degree of relevant laws } \\
\text { and regulations }\end{array}$ & 1.9 \\
\hline & foreign access condition & 2.3 \\
\hline & tax policy & 1.8 \\
\hline & $\begin{array}{l}\text { environment related laws and } \\
\text { regulations }\end{array}$ & 2.1 \\
\hline \multirow{5}{*}{$\begin{array}{l}\text { economic } \\
\text { environment }\end{array}$} & GDP & 1.8 \\
\hline & market scale & 2.2 \\
\hline & economic growth amplitude & 2.5 \\
\hline & inflation rate & 1.8 \\
\hline & to attract foreign investment & 2.4 \\
\hline \multirow{4}{*}{$\begin{array}{c}\text { financial } \\
\text { environment }\end{array}$} & exchange rate & 2.2 \\
\hline & development of securities market & 0.5 \\
\hline & banking institutions & 1.2 \\
\hline & financing convenience degree & 0.8 \\
\hline \multirow{4}{*}{$\begin{array}{l}\text { labor market } \\
\text { environment }\end{array}$} & the amount of labor & 1.9 \\
\hline & labor wages & 2.2 \\
\hline & labor welfare & 2.0 \\
\hline & labor quality & 0.5 \\
\hline \multirow{2}{*}{$\begin{array}{c}\text { natural } \\
\text { environment }\end{array}$} & geographic location & 2.7 \\
\hline & natural resources & 2.7 \\
\hline
\end{tabular}


On the basis of the data in the above table, the average value of the first level indicators is calculated. The results are shown in follow table.

TABLE V. The AVERage Value of the First LEVEl IndicAtors

\begin{tabular}{|c|c|}
\hline Indicator & Score \\
\hline Politics & 2.45 \\
\hline Law & 2.03 \\
\hline Economy & 2.14 \\
\hline Finance & 1.18 \\
\hline Labor & 1.65 \\
\hline Nature & 2.70 \\
\hline Global heat & 2.03 \\
\hline
\end{tabular}

According to the average value of the first level indicators, we can obtain the global heat is 2.03 , which belongs to the "hot" level, that is conducive to foreign investors to invest in the construction of traffic infrastructure in Laos.

On the political side, according to the heat analysis, the Lao political environment score of 2.45 points, belong to the "hot" level. It indicates that the political situation is relatively stable and beneficial to investors. Lao many political aspects are similar to our country, but investors still should pay much attention to the political risk, maintain close contact with local government and understand the wishes of the people lived near the construction, so as to avoid unnecessary losses.

Legal, economic, natural environment, respectively, scored 2.03, 2.14 and 2.7, are "hot" level, which are conducive to invest. Investors should fully understand related laws and regulations about the local transportation infrastructure construction, and comply with the local law.

The labor market environment, the score of 1.65 points, belong to the "warm" level, investors can invest. In the Lao labor market, there are advantages of the Lao employee's salary and welfare standards, but the high quality of labor is insufficient. Therefore, enterprises go to Laos to their transportation infrastructure investment, they should be mainly hire local workers at the grassroots level position, which can not only reduce the cost of construction, but also provide a lot of jobs for the local, enhance engineering construction to the support of the local people, achieve the win-win goals. And advanced technology, management personnel can be selected from the company and the local, and thus to protect the project better.

According to the heat analysis score, the lowest score is the financial environment in Laos, for 1.18. Therefore, foreign investors in Laos for transportation infrastructure investment should pay attention to pay attention to the financial environment and all of Laos banking system, securities market complete degree is not high, financing convenience is also poor in Laos local. Therefore, foreign investors should pay more attention to the choice of investment and financing models, innovative financing channels, to ensure the effective convergence of the project funds chain.

\section{CONCLUSION}

Laos transportation infrastructure has seriously hampered the development of its economy, there are many project of much-needed foreign investors to invest, the market is large. This paper analyzed the status of the political, economic, natural resources and other aspects of the Lao state, and analyzed the current situation, existing problems and investment environment of transportation infrastructure construction. And in view of the above research, based on the method of heat analysis, invited experts to score, so that the investment environment in Laos transportation infrastructure is hot, it is more suitable for investors to invest. However, the relevant laws and regulations should be carefully understood, for the low quality of labor quality in Laos, poor financing and other issues to conduct in-depth research, so as to obtain the maximum benefit.

\section{ACKNOWLEDGMENT}

I would like to express my sincere gratitude to all those who helped me during the writing of this thesis.

In the first place, I gratefully acknowledge the help of my supervisor, Mr Liu, who has offered me valuable suggestions in the academic studies. In the second place, I would like to express my heartfelt gratitude to my classmate, when my research was in trouble, they all gave me some help.

\section{REFERENCES}

[1] Pemasiri J. and Gunawardana, "Trends and Patterns of Foreign Direct Investment in Lao PDR," vol. 1, International Journal of Business and Management, 2008, pp. 4-57.

[2] Phouphet Kyophilavong, and Toshihisa Toyoda, "Foreign Capital Inflows in the Natural Resources Sector:Impacts on the Lao Economy,' The Future of Economic Integration in Asia, 2008, pp. 14-15.

[3] Festus Ebo Turkson, Agyapomaa Gyeke-Dako, and Emmanuel Bentum Amissah, "Foreign Direct Investment Spillovers and the Ghanaian Local Financial Environment," vol. 6, Modern Economy, 2015, pp. 10.

[4] S. Oparaocha, "Hmong women, opium cultivation and livestock production in Lao PDR," Gender, technology and development, 2002.

[5] Pa Nhia. D. Yang, Catherine A. and Solheim, “ Financial Management in Hmong Immigrant Families: Change and Adaptation," Hmong Studies Journal, 2008

[6] Bochaton Audrey, "Cross-border mobility and social networks: Laotians seeking medical treatment along the Thai border," Social science \& medicine, 2015

[7] Cohen Paul T, "The post-opium scenario and rubber in northern Laos: Alternative Western and Chinese models of development," vol. 2, International Journal of Drug Policy, 2009.

[8] Gordon Gregory, Vongvichit Eksavang, Hansana Visanou, and Torjesen Kristine, "A model for improving physician performance in developing countries: a three-year postgraduate training program in Laos," vol. 3, Academic Medicine, 2006.

[9] Vanthana Nolintha, and Idris Jajri, “The garment industry in Laos: technological capabilities, global production chains and competitiveness," vol. 1, Asia Pacific Business Review, 2016, pp. 221.

[10] Günther Slesak, Saythong Inthalath, Annelies Wilder-Smith, and Hubert Barennes, "Road traffic injuries in northern Laos: trends and risk factors of an underreported public health problems," vol. 11, Trop Med Int Health, 2015.

[11] Idoya Ferrero-Ferrero, María Jesús Muñoz-Torres, and María Ángeles Fernández-Izquierdo, "Changes in top management teamstrategies caused by the external financial environment," vol. 9, Leadership \& Organization Development Journal, 2015. 
[12] X.P. Sun, "Improve the Investment and Financing Environment and Promote Sustainable Development of Agriculture in Shandong Province, China," vol. 12, Management Science and Engineering, 2011, pp. 54.
[13] J.H. Jian, "The Change of Financial Environment and the Evolvement of Financial Goals," vol. 6, International Journal of Business and Management, 2009, pp. 44. 